5. Kromann N, Green A. Epidemiological studies in the Upernavir district, Greenland. Incidence ofsomet chronic disease 1950-1974. Acta Med Scand. 1980. №208(5). P. 401-6.

6. Rodriguez BL, Sharp DS, Abbott RD, et al. Fish intake may limit the increase in risk of coronary heart disease morbidity and mortality among heavy smokers. The Honolulu Heart Program. Circulation. 1996. №94(5). P. 952-56.

7. Donald B. Jump, Christopher M. Depner and Sasmita Tripathy. Omega-3 fatty acid supplementation and cardiovascular disease. J Lipid Res. 2012 December; 53:(12). P. 2525-2545.

8. Мицьо В. Кардиоваскулярные эффекты $\omega-3$ полиненасыщенных жирных кислот: влияние на прогноз после перенесенного инфаркта миокарда. Medical review. 2014. №2(30). P. 47-51.

DOI https://doi.org/10.30525/978-9934-26-182-4-11

\title{
ЗНАЧЕННЯ РЕЦЕПТОРІВ АНДРОГЕНІВ В ПЕРЕБІГУ ЗАХВОРЮВАННЯ У ПАЦІСНТОК 3 ТРИЧІ НЕГАТИВНИМ РАКОМ ГРУДНОЇ ЗАЛОЗИ
}

\author{
Лялькін С. А. \\ доктор медичних наук, старший дослідник, \\ старший науковий співробітник \\ Національний інститут раку \\ м. Київ, Украӥна
}

Андрогенові рецептори (АР) - стероїдні гормональні рецептори, які функціонують як класичний ліганд-активований інтрацелюлярний фактор транскрипції $[1,2]$. Експресія АР виражена в нормальній тканині грудної залози та більшості молекулярних підтипів раку грудної залози (РГЗ) $[2,3]$. Остаточну роль андрогенів у розвитку та прогресуванні РГЗ не встановлено. Наявність АР у пухлині залежить від молекулярного підтипу РГЗ і спостерігається у майже 90\% хворих на люмінальний А РГЗ, у 70-90\% - на люмінальний В РГЗ, у 60\% при HER2 позитивному типу та 10- 50 \% при тричі негативному РГЗ (ТНРГЗ) [4]. Слід зазначити, що прогностична та предиктивна роль АР для ТНРГЗ $є$ суперечливою. Дослідження Y. Kim et al. [5], продемонструвало, що для пацієнток 3 ТНРГЗ наявність експресії АР асоційована 3 кращим показником виживання без прогресування (ВР 0,42, 95\% ДІ 0,27-0,64). В мета-аналізі 
13 клінічних досліджень, проведеному Wang et al., за участю 2826 пацієнток з ТНРГЗ, позитивні АР виявлені у 24,4 \% хворих, доказано асоціацію АР с постменопаузальним статусом хворих, високим ступенем диференціювання пухлини (G1-G2) та підвищеним ризиком наявності метастазів в лімфовузлах [6]. Метою дослідження було вивчення прогностичної ролі АР у пацієнток з ТНРГЗ.

Матеріали та методи. Для оцінки клінічної значимості АР було проведено дослідження їх експресії в пухлинній тканині у 128 хворих на ТНРГЗ.

Імуногістохімічне (ІГХ) дослідження здійснювали на депарафінізованих зрізах пухлин РГЗ з використанням моноклональних антитіл (MкAT): Androgen Receptor Mous Monoclonal Antibody, Clone FR441DBS, США. Позитивними вважали пухлини, у яких було виявлено експресію АР більше, ніж у 10\% пухлинних клітин.

В рамках дослідження було проаналізовано взаємозв'язок АР 3 клінічними характеристиками пацієнток на ТНРГЗ, такими як стадія процесу на момент встановлення діагнозу, біологічними характеристиками пухлини (ступінь їі диференціювання $\mathrm{G}$, індекс проліферативної активності Кі-67); також були враховані вік та стан менструальної функції пацієнток.

Первинні дані обробляли методами дескриптивної статистики та досліджувались методами одно- та багатофакторної моделі пропорційних ризиків Кокса, достовірність відмінностей даних оцінювалась за коефіцієнтом Фішера. Визначали загальну виживаність хворих за методом Каплана-Майера.

Результати. Вік хворих на момент включення в дослідження коливався в межах від 27 до 76 років. Серед 128 пацієнток на ТНРГЗ позитивну експресію рецепторів андрогенів $(\mathrm{AP}+)$ в пухлинній тканині було виявлено у 51 (40\%) хворих, тоді як у решта 77 (60\%) - експресії рецепторів андрогенів виявлено не було (АР -). Варто зазначити, що пухлини $з$ позитивною експресією АР частіше зустрічались у старших пацієнток. Середній вік пацієнток на ТНРГЗ без експресії АР склав $45,5 \pm 4,7$ років, а у пацієнток, в пухлинах яких було виявлено експресію АР $-56,1 \pm 4,5$ років, відмінність між групами є статистично значимою $\mathrm{p}=0,002$.

У пацієнток на ТНРГЗ без експресії АР пухлини частіше діагностували у більш пізній стадії ( $\mathrm{p}=0,005)$, та частіше зустрічалось ураження аксилярних лімфовузлів ( $\mathrm{p}=0,01)$, порівняно з хворими, в пухлинах яких виявляли позитивну експресію АР. Проте, не було виявлено статистично достовірної різниці ступеня диференціювання пухлини $\mathrm{G}$ між групами. Також, не будо виявлено відмінностей за індексом проліферативної 
активності пухлини Кі-67. Так, середні значення Кі-67 у групі АР (-) пухлин склали 44,1 $15,6 \%$, а у групі АР $(+)$ пухлин $-48,6 \pm 13,6 \%(p=0,95)$.

Наступним етапом було досліджено безпосередній вплив експресії АР на загальну виживаність пацієнток з ТНРГЗ методом Каплана-Майєра. Медіана загальної виживаності була більша у хворих 3 експресією АР порівняно з тими, що іiї не мали (57 міс та 27 міс відповідно, p < 0,0001). Визначено, що п’ятирічна виживаність з моменту встановлення діагнозу у хворих 3 експресією $\mathrm{AP}(+)$ була вищою порівняно 3 пацієнтами без

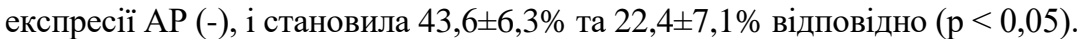

Також було вивчено вплив експресії АР, дослідженої у відсотках, на загальну виживаність за моделлю пропорційних ризиків Кокса (Табл. 1).

Таблиця 1

Відношення ризиків смерті у паціснтів на ТНРГЗ залежно від експресії андрогенових рецепторів

\begin{tabular}{|c|c|c|}
\hline Показник & Відсутня експресія АР & Наявна експресія АР \\
\hline АР (-) & - & 0.3446 \\
$\mathrm{n}=72$ & - & $0.2151-0.5520$ \\
\hline $\mathrm{AP}(+)$ & 2.9023 & - \\
$\mathrm{n}=44$ & $1.8116-4.6495$ & - \\
\hline
\end{tabular}

Порівняльний аналіз впливу рівня експресії АР у пацієнток на ТНРГЗ показав, що ризик смерті від РГЗ знижується в середньому на $3 \%, \mathrm{HR}=$ $0,97(95 \%$ ВI 0,96-0,99) на кожен відсоток зростання рівня експресії АР в тканині пухлини.

Таблиця 2

Прогностична роль стадії захворювання та експресії АP у пацієнток на ТНРГЗ (коефіцієнти двохфакторної моделі пропорційних ризиків Кокса)

\begin{tabular}{|c|c|c|c|}
\hline Факторна ознака & Коефіціснт моделі b & $\mathbf{P}$ & $\mathbf{9 5 \%} \mathbf{C I}$ \\
\hline Експресія АР & -1.0636 & 0.0001 & 0.2056 to 0.5798 \\
\hline Стадія ТNM & 0.4025 & $<0.0001$ & 1.2584 to 1.7772 \\
\hline
\end{tabular}

Аналіз двофакторної моделі пропорційних ризиків Кокса у нестратифікованій групі (табл. 2) показав, що виявлення захворювання у більш пізній стадії збільшує ризик смерті в середньому в 1,5 рази (HR 1,49; $95 \%$ BI 1,25 - 1,77) (p < 0,0001) на кожну градацію. Проте, наявність експресії АР на пухлинних клітинах пацієнток на ТНРГЗ зменшує ризик смерті в середньому в 3 рази (HR 0,35; 95\% BI 0,20 - 0,57) $(\mathrm{p}=0,0001)$. 
Таким чином, у нашому дослідженні доведено незалежне прогностичне значення експресії АР у пацієнток на ТНРГЗ при різних стадіях захворювання.

Висновки. Досліджено, що пухлини з позитивною експресією А Р частіше зустрічались у старших пацієнток на ТНРГЗ, $\mathrm{p}=0,002$.

Встановлено, що у пацієнток на ТНРГЗ без експресії АР (-) діагностували захворювання у більш пізній стадії $(\mathrm{p}=0,005)$ та частіше зустрічалось ураження аксилярних лімфовузлів $(\mathrm{p}=0,01)$, порівняно 3 хворими, в пухлинах яких виявляли позитивну експресію АР.

Доведено незалежне прогностичне значення експресії АР у пацієнтів 3 ТНРГЗ при різних стадіях захворювання. Медіана загальної виживаності була більша у хворих з експресією рецепторів андрогенів порівняно 3 тими, що іiі не мали (57 міс та 27 міс відповідно, p < 0,0001). П'ятирічна виживаність 3 моменту встановлення діагнозу у групі з наявною

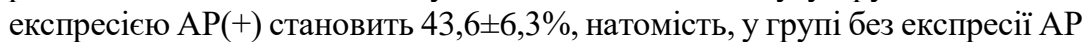
$(-)-22,4 \pm 7,1 \%,(\mathrm{p}<0,05)$.

Отже, результати наших досліджень свідчать про більш сприятливий перебіг тричі негативного раку грудної залози у хворих, пухлинні клітини яких експресують АР, проте, потребують подальшого вивчення.

\section{Література:}

1. Крылов, А. Ю. Андрогены и рак молочной железы (обзор литературы) / А. Ю. Крылов, Ю. В. Крылов // Вестник Витебского государственного медицинского университета. - 2015. - Т. 14, № 5. C. 5-15.

2. Gerratana L, Basile D., Buono G. et al. Androgen receptor in triple negative breast cancer: a potential target for the targetless subtype. Cancer Treat Rev. 2018 ; 68; 102-110.

3. P. Giovannelli, M. DiDonato, G. Galasso, et al. The androgen receptor in breast cancer. Front. Endocrinol. 2018; 9; 492.

4. Niemeier LA, Dabbs DJ, Beriwal S, Striebel JM, Bhargava R. Androgen receptor in breast cancer: Expression in estrogen receptor-positive tumors and in estrogen receptor-negative tumors with apocrine differentiation. Mod Pathol 2010;23:205 - 12.

5. Kim Y, Jae E, Yoon M. Influence of Androgen Receptor Expression on the Survival Outcomes in Breast Cancer: A Meta-Analysis. Breast Cancer. 2015;18(2):134-42.

6. Wang C, Pan B, Zhu H, Zhou Y, Mao F, Lin Y, et al. Prognostic value of androgen receptor in triple negative breast cancer: a meta-analysis. Oncotarget. 2016; 7:46482 - 91 . 